\title{
Construction of a Groundwater-Flow Model for the Big Sioux Aquifer Using Airborne Electromagnetic Methods, Sioux Falls, South Dakota
}

\author{
By Joshua F. Valder, Gregory C. Delzer, Janet M. Carter, Bruce D. Smith, and David V. Smith
}

\section{Introduction}

The city of Sioux Falls is the fastest growing community in South Dakota. In response to this continued growth and planning for future development, Sioux Falls requires a sustainable supply of municipal water. Planning and managing sustainable groundwater supplies requires a thorough understanding of local groundwater resources. The Big Sioux aquifer (fig. 1) consists of glacial outwash sands and gravels and is hydraulically connected to the Big Sioux River (Niehus and Thompson, 1998), which provided about 90 percent of the city's source-water production in 2015 (Jeff Dunn, City of Sioux Falls, written commun., 2016). Managing sustainable groundwater supplies also requires an understanding of groundwater availability. An effective mechanism to inform water management decisions is the development and utilization of a groundwater-flow model (fig. 2). Anderson and others (2015) stated that a groundwater-flow model provides a quantitative framework for synthesizing field information and conceptualizing hydrogeologic processes. These groundwaterflow models can support decision making processes by mapping and characterizing the aquifer. Accordingly, the city of Sioux Falls partnered with the U.S. Geological Survey (USGS) to construct a groundwater-flow model. Model inputs will include data from advanced geophysical techniques, specifically airborne electromagnetic (AEM) methods.

\section{Study Objectives}

The objectives of this study include characterization of the hydrogeologic framework of the Big Sioux aquifer near Sioux Falls, South Dakota, and construction of a groundwater-flow model to assess the vulnerability and sustainability of the Big Sioux aquifer. Results from this study could provide information on groundwater supplies and the potential effects groundwater pumping has on production wells and water levels in the Big Sioux River. More specifically, the primary benefits of the study include the following:

- an inventory of groundwater resources in the Big Sioux aquifer,

- estimates of hydrogeologic characteristics for construction of the groundwater-flow model (for example, saturated thickness, specific yield, and porosity),

- information on the potential effects of future wells on existing production wells,
- prediction of the fate and transport of contaminant plumes, and

- visualization of streamflow capture areas, which may be more vulnerable to contamination.

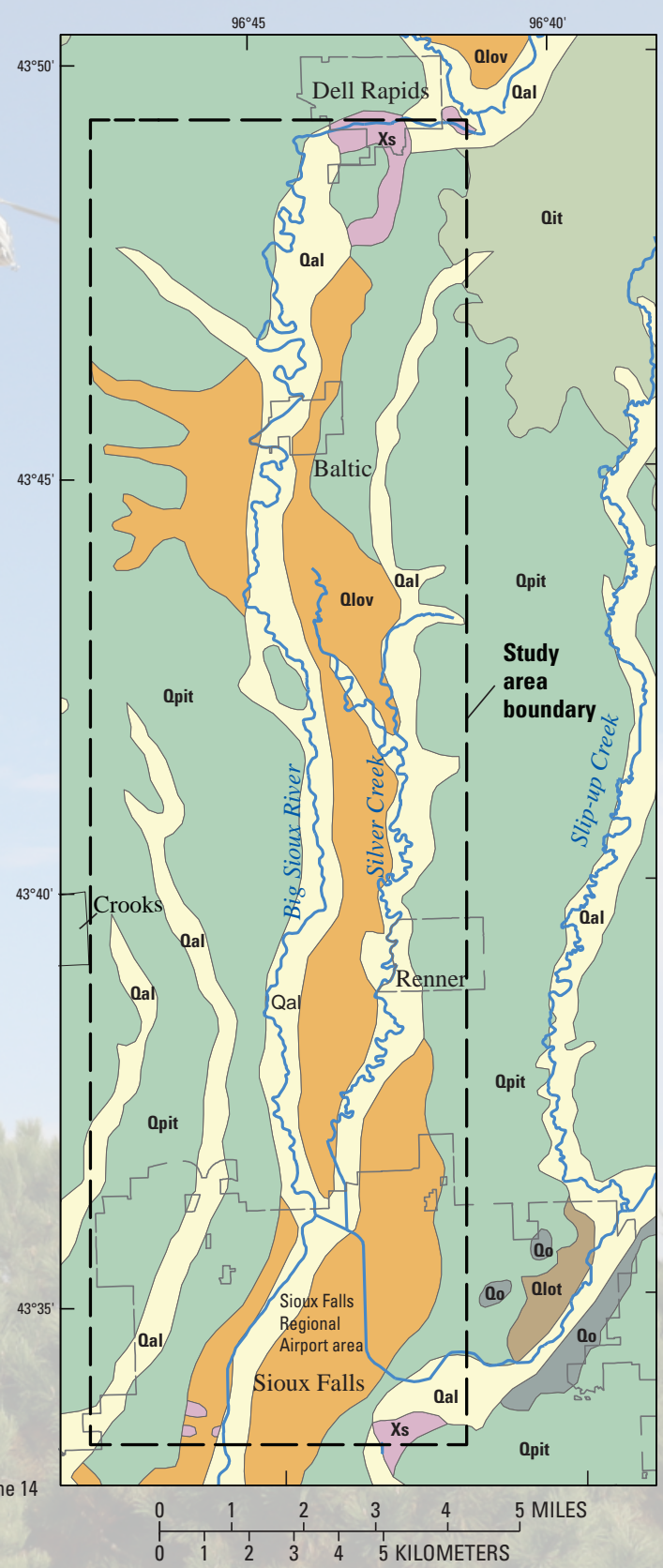

Figure 1. The study area and surficial geology near Sioux Falls, South Dakota. 


\section{Importance of a groundwater-flow model}

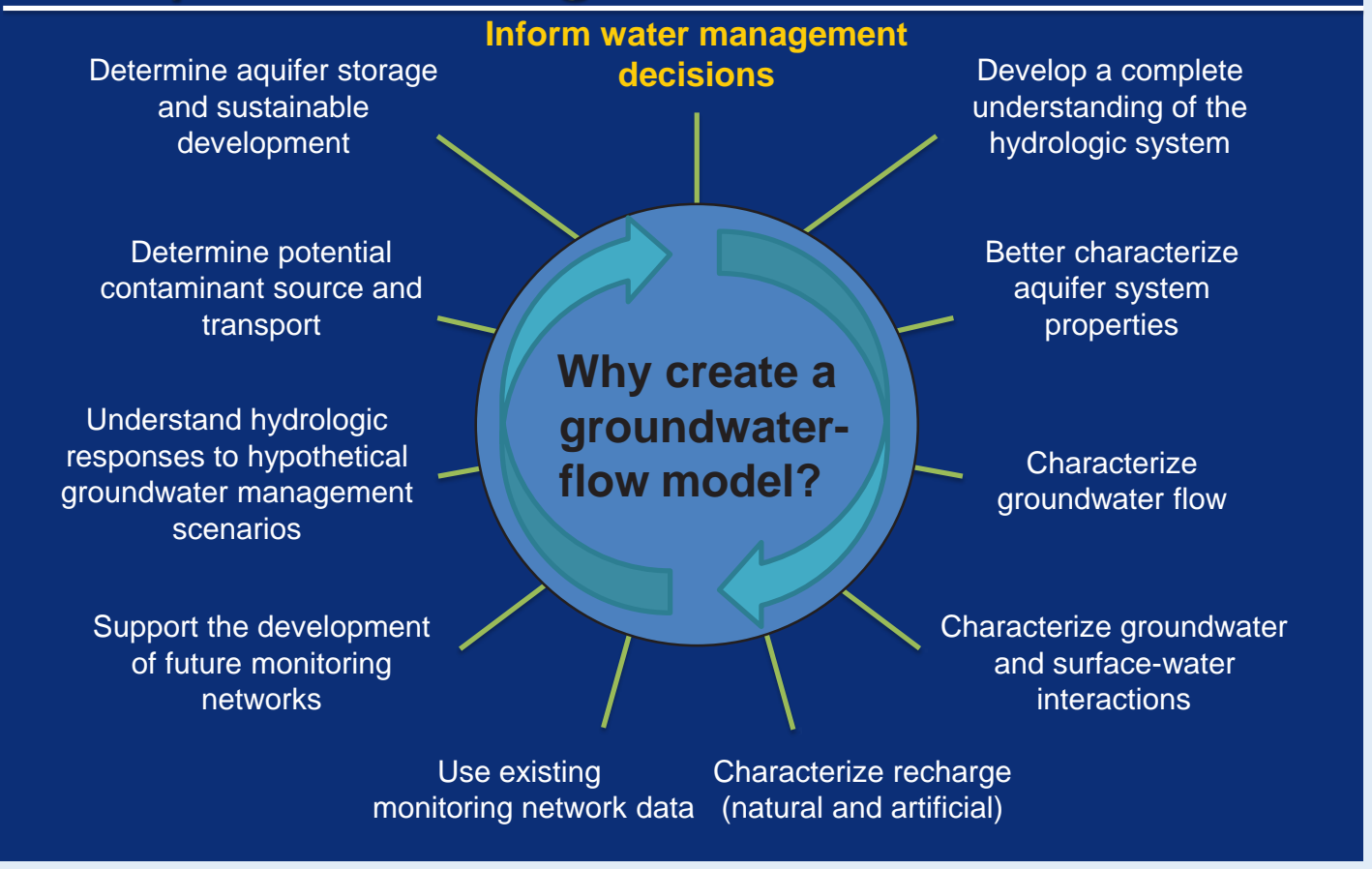

Figure 2. Various applications of groundwater-flow models.

\section{Groundwater-Flow Model Background}

Groundwater-flow models are used as a mechanism to improve understanding of groundwater processes in a study area (fig. 2). Models can be used to make projections, such as water-level changes based on the addition of production wells in an area, and investigate scenarios, such as drought or increased well pumping, to determine their effects. Models can guide the acquisition of needed hydrologic data. Groundwater-flow models also can be used as a tool by water-resource managers to answer questions related to the availability, sustainability, and vulnerability of a groundwater resource.

Generally, the groundwater-flow model construction process begins with characterizing the physical properties of an aquifer, which includes defining the extent and thickness of the aquifer. Geological sediments deposited during successive glacial advances and retreats pose a challenge for mapping buried aquifer channels, like the Big Sioux aquifer, because these channels cannot be identified from surface geology. Additionally, the aquifer channels commonly are covered by glacial drift, which includes material such as gravel, sand, or clay transported and deposited by a glacier or by glacial meltwater. Although numerous test holes and observation wells were drilled and installed for a previous study of the Big Sioux aquifer (Lindgren and Niehus, 1992) that provide information about the subsurface geology, the distance between the test holes and wells varies from one to several miles; therefore, geology and aquifer characteristics between these points must be interpolated. An advantage of using airborne geophysical methods is they can provide nearly continuous swaths of data, filling these gaps.

The AEM methods are geophysical measurements that measure variations in the electrical resistivity of subsurface materials by sensing the flow of electrical currents in different types of geologic deposits (Smith and others, 2007). An AEM survey has several advantages over ground-based surveys, including the ability to map large areas with a higher density of data coverage and the ability to cover areas with rugged terrain, and is a noninvasive method of data collection using a helicopter or fixed-wing airplane (Ball and others, 2011). Historically, AEM surveys have been used to map mineral deposits; however, it has been increasingly used for geologic and hydrologic studies (Smith and others, 2007). The AEM method has proven effective for mapping groundwater supplies because of the distinctive resistivity signatures of water-bearing geologic materials (Smith and others, 2007); thus, AEM methods can be used to map the thickness and extent of aquifers, such as the Big Sioux aquifer, and provide important input data for a groundwater-flow model.

\section{Airborne Electromagnetic Method Approach}

An AEM survey using the RESOLVE frequency domain system (Smith, 2010) was completed in 2015 through a coordinated effort by the city of Sioux Falls, USGS South Dakota Water Science Center, USGS Crustal Geophysics and Geochemistry Science Center, and CGG Canada Services. The RESOLVE frequency domain system was chosen for this study because it has the best resolution for near-surface material and is least influenced by electromagnetic noise, such as utility power lines. A helicopter flown by CGG Canada Services was used to carry a large cylindrical sensor, called a "bird" (fig. 3), which transmitted electromagnetic waves into the ground. The survey acquired about 540 line-miles of AEM data for the Big Sioux aquifer in the study area (fig. 4). The AEM data were collected over a total area of about 56 square miles, primarily over the flood plain of the Big Sioux River between Dell Rapids and Sioux Falls, S. Dak., and secondarily over the Sioux Falls Regional Airport.

Although ground-based geophysical methods can be used to characterize buried channels, depth-to-bedrock, and aquifer properties, the Big Sioux aquifer is too large for comprehensive ground-based geophysical techniques. Ground-based methods 

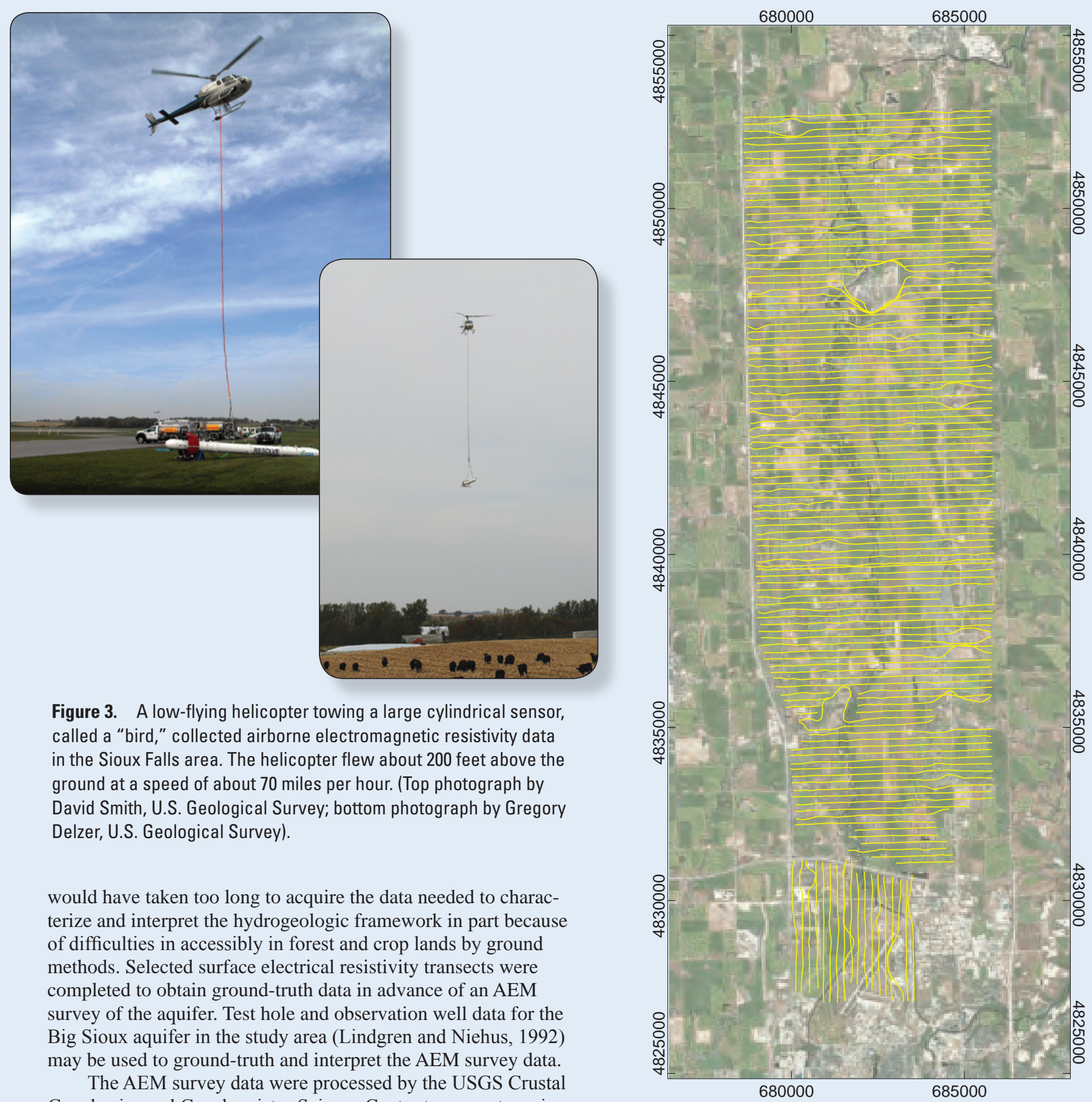

Figure 3. A low-flying helicopter towing a large cylindrical sensor, called a "bird," collected airborne electromagnetic resistivity data in the Sioux Falls area. The helicopter flew about 200 feet above the ground at a speed of about 70 miles per hour. (Top photograph by David Smith, U.S. Geological Survey; bottom photograph by Gregory Delzer, U.S. Geological Survey).

would have taken too long to acquire the data needed to characterize and interpret the hydrogeologic framework in part because of difficulties in accessibly in forest and crop lands by ground methods. Selected surface electrical resistivity transects were completed to obtain ground-truth data in advance of an AEM survey of the aquifer. Test hole and observation well data for the Big Sioux aquifer in the study area (Lindgren and Niehus, 1992) may be used to ground-truth and interpret the AEM survey data.

The AEM survey data were processed by the USGS Crustal Geophysics and Geochemistry Science Center to generate resistivity-depth sections used in two-dimensional maps and threedimensional volumetric visualizations (Smith and others, 2016). Resistivity spatial datasets may be used to characterize the distribution of materials composing this glacial outwash aquifer. The depth sections more clearly define the depth and extent of the Big Sioux aquifer and the underlying Precambrian-age Sioux Quartzite bedrock (Niehus and Thompson, 1998).

The AEM methods can directly contribute to construction of a detailed hydrogeologic framework of the Big Sioux aquifer. Components of the hydrogeologic framework include estimates of other hydrogeologic characteristics, such as saturated thickness, specific yield, and porosity. These characteristics can be obtained using previous investigations, drillers' logs, and aquifer tests, where applicable. After construction of the hydrogeologic

Base from U.S. Geological Survey digital data

Map image: Google earth, (c) 2016 Google, Image Landsat Universal Transverse Mercator projection, zone 14

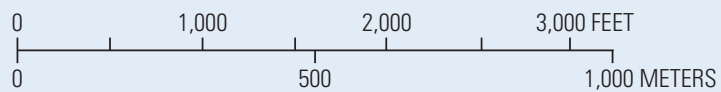

Figure 4. The flight lines (yellow) for the airborne electromagnetic resistivity survey. About 540 line-miles of data were acquired for the Big Sioux aquifer in the study area.

framework for the Big Sioux aquifer, a groundwater-flow model can be constructed and calibrated. The groundwater-flow model can provide an opportunity to evaluate aquifer development scenarios and enhance the decision-making processes by the city of Sioux Falls for future municipal water projects. 


\section{References Cited}

Anderson, M.P., Woessner, W.M., and Hunt, R.J., 2015, Applied groundwater modeling - Simulation of flow and advective transport (2d ed.): Elsevier Inc., 564 p.

Ball, L.B., Smith, B.D., Minsley, B.J., Abraham, J.D., Voss, C.I., Astley, B.N., Deszcz-Pan, Maria, and Cannia, J.C., 2011, Airborne electromagnetic and magnetic geophysical survey data of the Yukon Flats and Fort Wainwright areas, central Alaska, June 2010: U.S. Geological Survey Open-File Report 2011-1304, 21 p. [Also available at http://pubs.usgs.gov/ of/2011/1304/.]

Lindgren, R.J., and Niehus, C.A., 1992, Water resources of Minnehaha County, South Dakota: U.S. Geological Survey Water-Resources Investigations Report 91-4101, 80 p. [Also available at https://pubs.er.usgs.gov/publication/wri914101.]

Martin, J.E., Sawyer, J.F., Fahrenbach, M.D., Tomhave, D.W., and Schulz, L.D., 2004, Geologic map of South Dakota: South Dakota Geological Survey, 1 sheet, scale 1:500,000.

Niehus, C.A., and Thompson, R.F., 1998, Appraisal of the water resources of the Big Sioux aquifer, Lincoln and Union Counties, South Dakota: U.S. Geological Survey Water-Resources Investigations Report 97-4161, 37 p. [Also available at https://pubs.er.usgs.gov/publication/wri974161.]
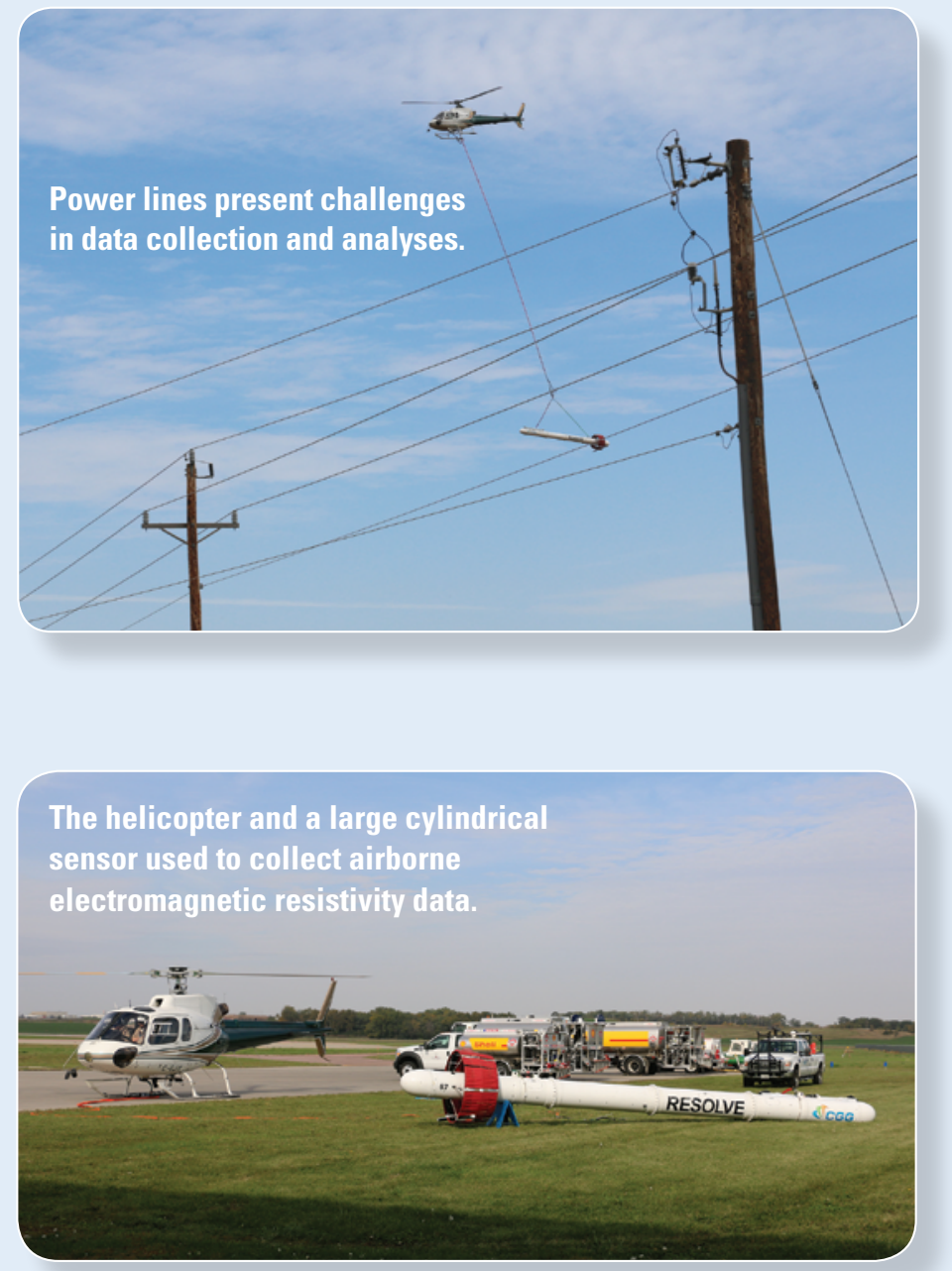

Smith, Richard, 2010, Airborne electromagnetic methodsApplications to minerals, water and hydrocarbon exploration: Canadian Society of Exploration Geophysicists, CSEG Recorder, v. 35, no. 3, p. 7-10.

Smith, B.D., Grauch, V.J.S., McCafferty, A.E., Smith, D.V., Rodriguez, B.R., Pool, D.R., Deszcz-Pan, Maria, and Labson, V.F., 2007, Airborne electromagnetic and magnetic surveys for ground-water resources-A decade of study by the U.S. Geological Survey, in Milkereit, B., ed., Proceedings of Exploration 07-Fifth decennial international conference on mineral exploration: Conference held September 9-12, 2007, Toronto, Canada, p. 895-899.

Smith, David, Deszcz-Pan, Maria, Smith, Bruce, Koth, Koth, and Dunn, Jeff, 2016, High-resolution airborne electromagnetric survey of the Big Sioux aquifer, Sioux Falls, South Dakota: Symposium on the Application of Geophysics to Engineering and Environmental Problems 2016, p. 21-25. [Also available at http://dx.doi.org/10.4133/SAGEEP.29-005.]

Tomhave, D.W., 2001, First occurrence of aquifer materials in Minnehaha County, South Dakota: South Dakota Geological Survey, Aquifer Materials Map 9, 1 sheet, scale 1:100,000. [Also available at http://www.sdgs.usd.edu/pubs/PDF/ AM-09_20010629.pdf.]

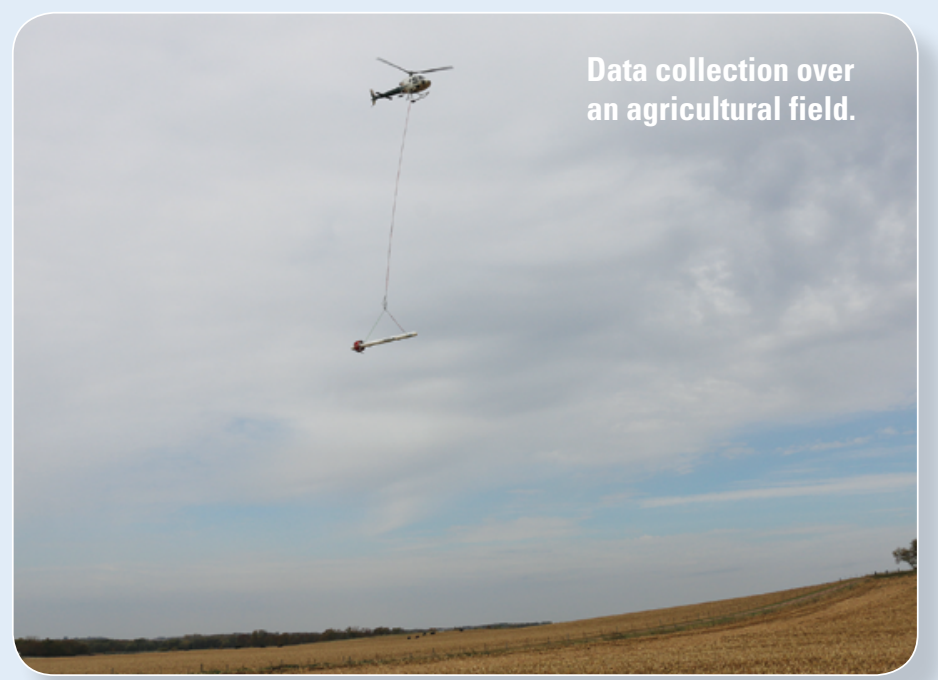

For more information, contact: Director, USGS South Dakota Water Science Center 1608 Mountain View Road Rapid City, South Dakota 57702

http://sd.water.usgs.gov/ 